\title{
Pancreatic Enzyme Supplementation in Normal and Exocrine Pancreatic Insufficient Pigs
}

\author{
By Hannu Salonıemı, Tımo V. Kalima and Timo Rahko \\ Department of Animal Hygiene and Pathology, College of Veterinary Medicine, and \\ The Second Department of Surgery, University of Helsink1, Helsinki, Finland.
}

\begin{abstract}
Saloniemi, H.,T. V. Kalima and T. Rahko: Pancreatic enzyme supplementation in normal and exocrine pancreatic insufficient pigs. Acta vet. scand. 1989, 30, 367-370. - The effect of pancreatic enzyme preparation (Combizyme Forte granulate ${ }^{8}$ ) on the growth rate of normal, sham-operated and pancreatic duct ligated growing pigs was studied in 2 trials. In the first trial 6 normal Yorkshire pigs were fed a pancreatic enzyme supplement and 6 other pigs from the same litter were fed without supplementation. The growth rate over a period of 4 weeks was not significantly greater in the supplemented group. In a second trial exocrine pancreatic insufficiency, without diabetic symptoms, was produced in. 12 pigs (aged 1.5 months and weighing $14 \mathrm{kgs}$ ) by ligation of the main pancreatic duct. The growth rates over a period of 20 days after surgery were $240 \mathrm{~g}, 454 \mathrm{~g}$ and $483 \mathrm{~g} /$ day in ligated pigs, in ligated pigs supplemented with pancreatic enzyme and in shamoperated control pigs, respectively. The difference between the ligated groups was significant $(p<0.01)$ indicating the efficiency of the pancreatic enzyme therapy.
\end{abstract}

pancreatic enzyme therapy; experımental pancreatic insufficiency.

\section{Introduction}

Oral enzyme therapy has been used in the treatment of various types of exocrine pancreatic insufficiency in man. However, the levels of nutrient absorption by these patients generally remain below normal. The need to develop a more effective pancreatic enzyme preparation is therefore evident.

The development of enzyme preparations requires a suitable animal model, and the digestive system of the pig closely resembles that of man (Mount \& Ingram 1971). Ligation of the pancreatic duct causes an exocrine pancreatic insufficiency, but this technique is not very often used in pigs (Pekas et al. 1964, Imondi et al. 1972). Nevertheless, the pig model seems to be the best animal model in pancreatic enzyme studies (Rahko et al. 1985).

The aim of the first trial in this study was to determine the effect of a new oral pancreatic enzyme preparation on the weight gain of normally reared pigs. In a second trial chronic pancreatitis and exocrine pancreatic insufficiency were produced in pigs by pancreatic duct ligation and the effect of the pancreatic enzyme preparation was tested.

\section{Materials and methods}

In the feeding experiment 12 Yorkshire pigs aged 33 days from the same litter were used. The pigs were divided into 2 treatment groups. The mean weights of the pigs were $9.5 \pm 1.9$ (s.d.) $\mathrm{kg}$ and $9.6 \pm 2.3 \mathrm{~kg}$ and both groups included 4 gilts and 2 castrated pigs. In the pancreatic duct ligation experiment a total of 22 Yorkshire pigs aged 40-47 days were used. The mean weight of the pigs before surgery was $13.6 \pm 2.5 \mathrm{~kg}$. 
Two pigs were lost after surgery and 5 were removed due to incomplete duct ligation.

The pigs were fed ad libitum with a commercial pig feed containing $17 \%$ protein and $3 \%$ fat. The feeding experiment was carried out over two 14-day periods. One group received feed supplemented with $10 \mathrm{~g}$ of the pancreatic enzyme preparation (Combizyme Forte granulate ${ }^{\circledR}, 300000$ FIP-units lipase, 15000 FIP-units protease and 200000 FIPunits amylase) per day per animal for 14 days. For the next 14 days the group was fed the same feed without enzyme supplementation. A second group first received feed without enzyme supplementation for 14 days and then feed supplemented with the enzyme preparation (10 g/day per animal) for 14 days. All pigs were weighed 5 times a week.

In the ligation experiment, exocrine pancreatic insufficiency was produced by ligation of the main pancreatic duct and dissection of the other parts of the head of the pancreas from the duodenum. All excess manipulation of the pancreas was avoided. Three control pigs were sham-operated being subjected only to laparotomy. After the operation $10 \mathrm{~g}$ of the pancreatic enzyme preparation was added onto the diets of 7 ligated pigs. Five ligated pigs and 3 control pigs were fed without enzyme supplementation. The fat content of diets was gradually increased to $20 \%$ by using a commercial mink feed. The pigs were weighed daily for 20 days. At the end of the experiment the pigs were necropsied (Rahko et al. 1987) and the protease activity of the duodenal content and, in some ligated animals, also that of the dilated pancreatic ducts were determined by the radial enzyme diffusion method (Westermarck 1982). Serum calcium, magnesium and glucose were also determined.

\section{Results}

In the feeding experiment weight gain over the first 14-day period was $360 \pm 111 \mathrm{~g} /$ day in the enzyme supplemented group and in the control group $332 \pm 42 \mathrm{~g} /$ day. Following change of treatment the weight gain of the enzyme supplemented group was $636 \pm$ $100 \mathrm{~g} /$ day as compared to $596 \pm 67 \mathrm{~g} /$ day in the control group. The differences between the groups are not statistically significant.

Weight and weight gains of the pigs in the ligation experiment are reported in Table 1. The gain of the ligated pigs without enzyme supplementation was significantly lower ( $p$ $<0.01)$ than the gain of the sham-operated or enzyme sypplemented pigs. At the end of

Table 1. Weight gain of pigs during 20 days after ligation of the pancreatic duct (s.d. = standard deviation).

\begin{tabular}{|c|c|c|c|c|c|c|c|}
\hline \multirow[t]{3}{*}{ Treatment } & \multirow{3}{*}{$\begin{array}{l}\text { Number } \\
\text { of pigs }\end{array}$} & \multirow{2}{*}{\multicolumn{2}{|c|}{$\begin{array}{l}\text { Weight (kg) } \\
\text { at the time } \\
\text { of operation }\end{array}$}} & \multicolumn{4}{|c|}{ Weight gain } \\
\hline & & & & \multicolumn{2}{|c|}{$g /$ day } & \multicolumn{2}{|c|}{$\% /$ day } \\
\hline & & mean & $\mathrm{sd}$ & mean & sd & mean & sd \\
\hline Sham-operation & 3 & 13.5 & 3.5 & $483^{a}$ & 104 & $3.6^{\mathrm{a}}$ & 0.3 \\
\hline $\begin{array}{l}\text { Ligation + enzyme } \\
\text { supplementation }\end{array}$ & 7 & 13.4 & 1.5 & $454^{a}$ & 126 & $3.4^{\mathrm{a}}$ & 0.9 \\
\hline Ligation & 5 & 13.8 & 2.4 & $240^{\mathrm{b}}$ & 95 & $1.7^{\mathrm{b}}$ & 0.8 \\
\hline
\end{tabular}

a, b Means with different superscripts in a column are significantly different at $\mathrm{p}<0.01$. 
the experiment, serum glucose, calcium and magnesium levels were normal and glucose tests in urine were negative.

The protease activity in the duodenal content of the ligated pigs was low, the diameter of the cleared zone in the radial enzyme diffusion test being $<10 \mathrm{~mm}$ compared to that of the sham-operated pigs (> $15 \mathrm{~mm}$ ). No difference between enzyme-treated groups was detected.

\section{Discussion}

In pigs the activities of digestive enzymes increase condiserably during the first weeks of life (Mount \& Ingram 1971). It seems possible that pancreatic enzyme supplementa tion increases digestive capacity as well as retention of nutrients in the normal pig intestine. In our feeding trial the increase in daily gain was so small as to preclude any economic basis for the use of pancreatic enzyme supplementation in normal feeding. However, enzyme treatments in feed processing are still very useful.

By using a method of pancreatic duct ligation to exclude exocrine pancreatic secretion, it is possible to measure the effect of oral pancreatic enzyme supplementation. The ligation produces typical chronic pancreatitis (Rahko et al. 1987, 1988), which sharply reduces both fat and protein absorption (Imondi et al. 1972). In the study of Imondi et al. the pancreatic supplementation employed resulted in a marked increase in fat absorption but not as good as an increase in protein absorption. The weight gain of ligated pigs supplemented with pancreatic enzyme was also significantly less than that of controls (Imondl et al. 1972). In our study, pancreatic enzyme supplementation increased weight gain to almost the same level as controls. The pancreatic enzyme preparation employed seems to be very usefull in the therapy of exocrine pancreas insufficiency.

Determinations of protease activity in the duodenal contents of the ligated pigs gave significantly lower values as compared to those of controls. Failure to produce and secrete exocrine enzymes is explained by the fact that almost all glandibular acini were destroyed due to ligation (Rahko et al. 1987). Morphological studies revealed that acinar tissues were replaced by proliferations of immature epithelial ducts and adipose and connective tissues. On the other hand, the number and size of the endocrine islets appeared to have increased and their cells were normally functioning. This is in accordance with the findings of normal glucose metabolism in the present study. Ultrastructural studies of Langerhans islets ( $R a h$ ko et al. 1988) also confirmed undisturbed endocrine function of the pancreas in ligated pigs. The epithelial cells of the endocrine ducts, on the contrary, were immature with respect to the production and secretion of enzymes (Rahko et al. 1987, 1988).

\section{References}

Imondl $A R$, Stradley $R P$, Wolgemuth $R \cdot$ Enzyme replacement therapy in the pancreatic duct ligated swine. Proc. Soc. Exp. Biol. Med. 1972, 141, 367-372.

Month LE, Ingram $D L$ The pig as a laboratory animal. Academic Press, London and New York 1971.

Pekas JC, Hays VW, Thompson AM Exclusion of the exocrine pancreatic secretion: effect on digestibility of soybean and milk protein by baby pigs at various ages. J. Nutrition 1964, 92, 277-286.

Rahko T, Grönlund AM, Kalıma TV, Saloniemi $H$ : A new animal model for exocrine pancreatic insufficiency. Path. Res. Pract. 1985, 180, 309.

Rahko T, Kalıma TV, Saloniemı H: Pancreatic duct obstruction in the pig: Light microscopy 
of chronic pancreatitis. Acta vet. scand. 1987, 28, 285-289.

Rahko T, Kalima TV, Saloniemi $H$ Pancreatic duct obstruction in the pig: Electron microscopy of chronic pancreatitis. Acta vet. scand. 1988, 29, 255-258.

Westermarck $E$. The diagnosis of pancreatic degenerative athropy in dogs - a practical method. Acta vet. scand. 1982, 23, 197-203.

\section{Sammanfattning}

Pankreasenzymtillskott hos normala svin och hos svin med exokrin pankreasinsufficiens

Effekten av ett pankreasenzympreparat (Combizyme Forte granulate ${ }^{\circledR}$ ) på tillväxten av normala, skenopererade och bukspottskörtelgång-ligerade svin stuerades $\mathrm{i}$ två försök. I det första försöket utfodrades sex normala Yorkshire svin med pankreasenzymtillskott och sex andra från samma kull utfodrades utan tillskot. Tillväxten under en fyra veckors period var inte signifikant större 1 tillskottsgruppen. I det andra försöket förorsakedes exokrın pankreasınsuffisiens (inga diabetessymptom) åt tolv svin (ålder 1,5 månad, levande vikt 14 $\mathrm{kg})$ genom at ligera bukspottskörtelgången. Tillväxten under 20 dagar efter operationen var $240 \mathrm{~g}$, 454 och $483 \mathrm{~g} /$ day i den ligerade gruppen, i den ligerade gruppen med enzymtillskott och i den skenopererade kontrolgruppen. Skillnaden mellan de ligerade grupperna var signifikant $(p<0.01)$, vilket visar den positiva effekten av enzymterapın.

(Accepted December 1, 1988)

Reprints may be requested from: Hannu Saloniem1, Department of Animal Hygiene,

College of Veterinary Medicine, P. O. Box 6, 00581 Helsinki, Finland. 